\title{
A NOTE ON THE EARTHQUAKES OF THE SOUTH AFRICAN TABLE-LAND.
}

\author{
By J. R. Sutton, Sc.D., F.R.S.S.Af.
}

(Read July 17, 1912.)

Occasional shocks of earthquake are felt on the South African Tableland. As a rule, although they extend over vast areas at a time, they are too slight to do much harm; but they may at times attain to some violence, and cause damage and loss of life. One, felt last February, was sufficiently severe to be recorded by seismographs in Europe. They seem to have some sort of relationship to barometric disturbances, and therefore in this respect are akin to the mud-rushes which were common in the Kimberley mines some years ago. Since the establishment of the observatory at Kenilworth there have been four earthquakes of sufficient intensity to be plainly felt. 'The following are the daily average values of the barometric pressure (from hourly readings) for a few days before and after these shocks:-

1. Earthquake at 10.13 P.m., July 31, 1903.

Barometer.

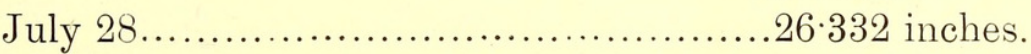

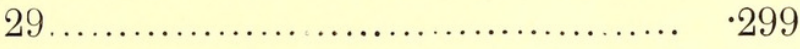

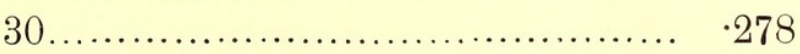

$31 \ldots \ldots \ldots \ldots \ldots \ldots \ldots \ldots \ldots \ldots \ldots \ldots \ldots \ldots \ldots \ldots+274$

Aug. 1 ................................. $\cdot 323$

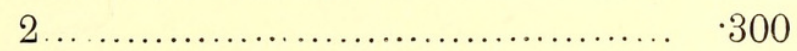

3............................... 276 
2. Earthquake at 10.35 P.м., Sept. 26, 1908.

Barometer.

Sept. 21 $26 \cdot 278$ inches.

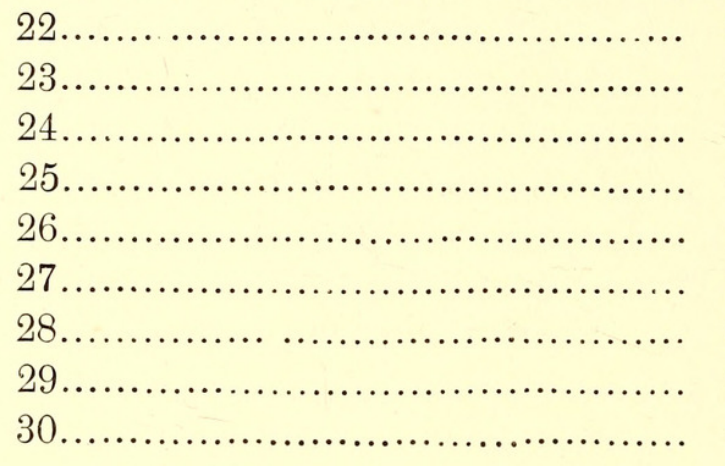

241

$\cdot 212$

$\cdot 150$

$\cdot 164$

$\cdot 092$

.003

$\cdot 065$

$\cdot 104$

$\cdot 130$

3. Earthquake at 8.10 P.м., Oct. 21, 1910.

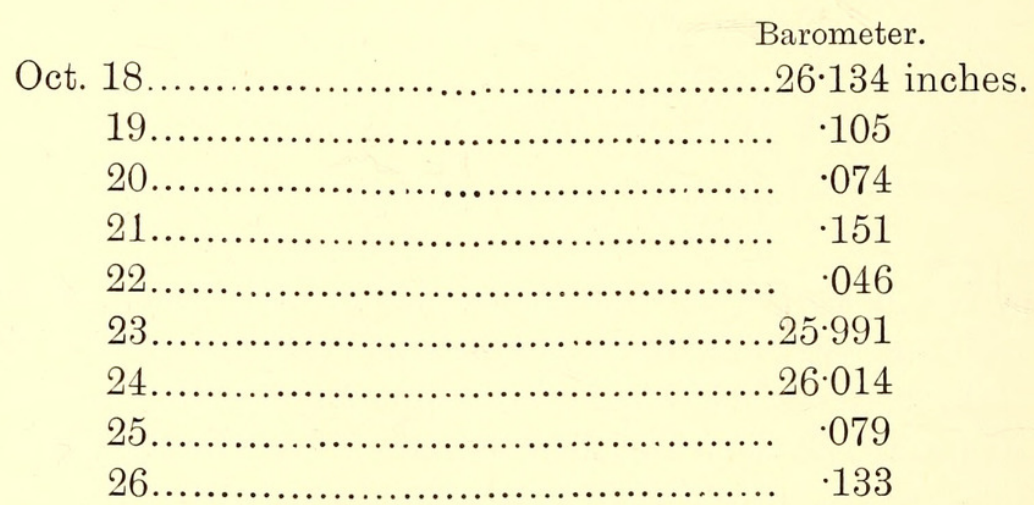

Coincident with this earthquake there was also a small but rapid variation of atmospheric pressure not shown in the hourly numbers.

4. Earthquake (Two Shocks) at 3.5 P.м., AND Just before 4 P.M., FEB. 20, 1912.

Barometer.

Feb. 16 26.083 inches.

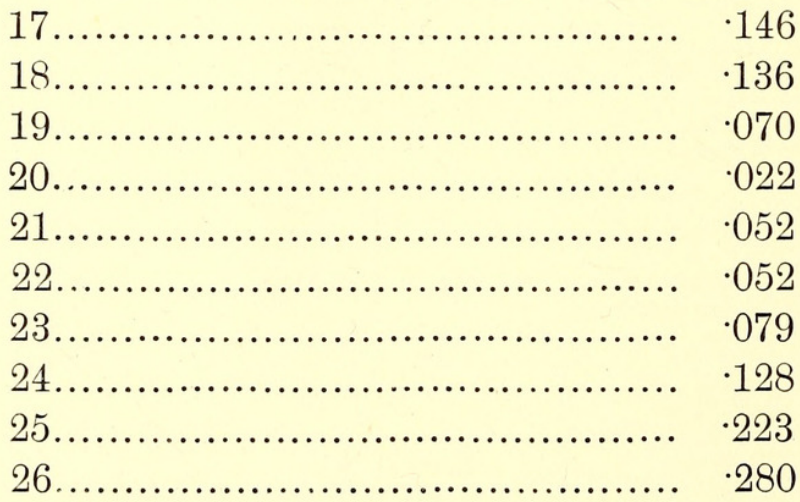


Of course the diurnal oscillation of barometric pressure is superimposed on these daily averages, accentuating the disturbances very largely. For example, the hourly pressures on Feb. 20, 1912, were:-

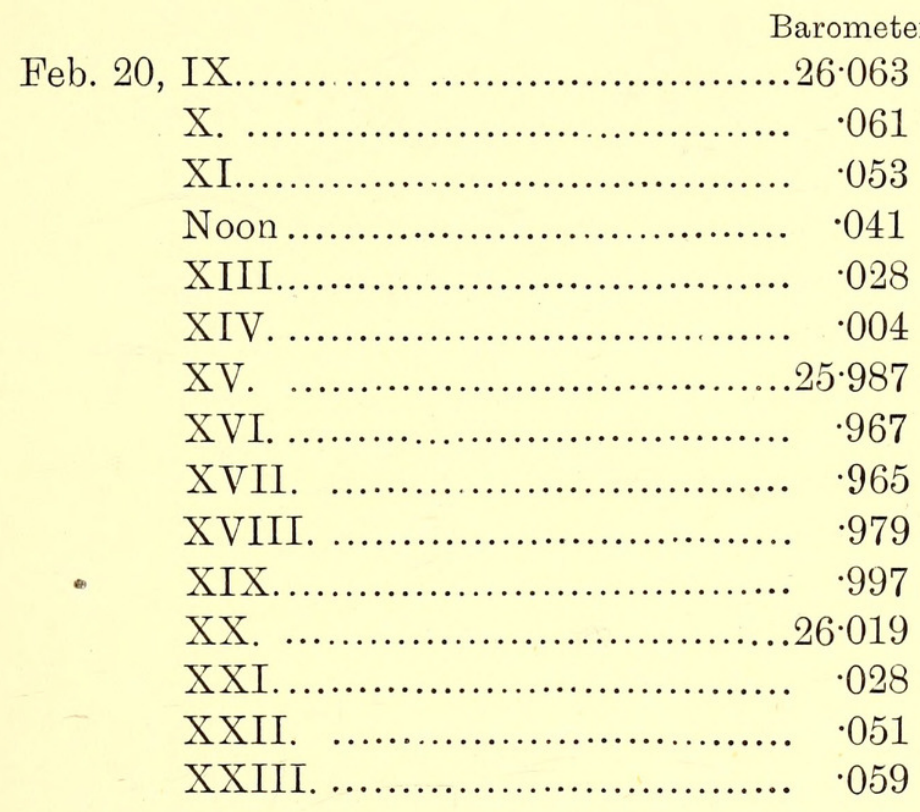

From which it appears that the two shocks of this day not only came when the barometer was at its lowest on the days' averages, but nearly at the time when it was lowest for the day itself.

It would be unsafe to argue from these few cases that an earthquake can only occur in South Africa when there is some amount of barometric disturbance. But it is not unlikely that when other conditions (say the flow of underground water carrying away lime in solution, and so making the support of the earth's crust at the spot unstable) are favourable to earth-movement, the passage of a barometric disturbance across the continent may decide the time when the movement shall take place. The idea that barometric disturbances have some influence over earthmovements is by no means a new one. The fact, e.g., that the earthquakes of China are most frequent in summer, Mr. N. F. Drake explains as due to the rapid and strong variations of atmospheric pressure, assisted by the heavy rain-storms, which occur in summer. [See the Bulletin of the Seismological Society of America for March, 1912.] 


\section{$2 \mathrm{BHL}$ Biodiversity Heritage Library}

Sutton, J R . 1913. "A NOTE ON THE EARTHQUAKES OF THE SOUTH AFRICAN

TABLE-LAND." Transactions of the Royal Society of South Africa 3, 195-197. https://doi.org/10.1080/00359191309519691.

View This Item Online: https://www.biodiversitylibrary.org/item/182860

DOI: https://doi.org/10.1080/00359191309519691

Permalink: https://www.biodiversitylibrary.org/partpdf/175514

\section{Holding Institution}

Smithsonian Libraries

\section{Sponsored by}

Biodiversity Heritage Library

\section{Copyright \& Reuse}

Copyright Status: Not in copyright. The BHL knows of no copyright restrictions on this item.

This document was created from content at the Biodiversity Heritage Library, the world's largest open access digital library for biodiversity literature and archives. Visit BHL at https://www.biodiversitylibrary.org. 